\title{
Risk factors of stunting occurrence in toddlers at Puskesmas Klungkung 1 2016/2017
}

\author{
LG Pradnyawati ${ }^{1 *}$ \\ ${ }^{1}$ Faculty of Medicine and Health Sciences, Universitas Warmadewa \\ *pradnyawati86@gmail.com
}

\begin{abstract}
Stunting is a growth disorder based on measurement of PB / U or TB / U characterized by a short body state. Toddlers were categorized short if the z-score of the scores is less than -2SD. In Indonesia $29 \%$ of children are short category. There are several risk factors that influence stunting including short-term pregnancy, mother's height, Low Birth Weights, number of children, age of MP-ASI, exclusive breastfeeding and frequency of infection history with stunting in toddlers. The purpose of this study was to determine the risk factor of stunting in toddlers at Puskesmas Klungkung I. This research is a case-control research with retrospective approach. The sample size used in this study were 35 case samples and 70 control samples, through purposive sampling technique. The data collected in the form of primary data and secondary data. Data were analyzed by bivariate analysis with chi square test and multivariate analysis with multiple logistic regression. Chi square test showed that the risk factors for stunting were Low Birth Weights, exclusive breastfeeding, age of MP-ASI, frequency of infection history and mother's height. Gestational distance and the number of children were not risk factor for stunting in this study. Multiple logistic regression test showed Low Birth Weight (OR $=21,98 ; 95 \%$ CI: $2.04-237,69)$ and mother height $(\mathrm{OR}=7,37 ; 95 \%$ CI: $1,94-28,02)$ became dominant risk factor of stunting incidents in toddlers at Puskesmas Klungkung I. These results indicate that mother's height and Low Birth Weights are the risk factors for stunting. Therefore, they need more attention to reduce the incidence of stunting
\end{abstract}

Keyword : Stunting, Toddlers, Puskesmas Klungkung.

\section{Introduction}

Indonesia is included in the 17 countries among 117 countries that have three nutritional problems, which are stunting, wasting, and overweight in children under five (balita) [1]. To be able to identify the nutritional status and health of children under age of five, growth is one of the best indicators that can be used. There are three indicators that are often used to measure the occurrence of disruption of growth in toddlers, namelyheight according to age (Tinggi Badan menurut Umur or TB / U), weight according to age (Berat Badan menurut Umur or BB / U), and weight according to height (Berat Badan menurut Tinggi Badan or BB / TB). Stunting is a growth disorder characterized by a body condition that tends to be short to beyond the deficit $-2 \mathrm{SD}$ (standard deviations) below the median height that is measurable with TB / U [2].

A region is considered to have a mild stunting problem when the prevalence is in the range of 20 to $29 \%$, moderate if it is in the range of 30 to $39 \%$, and weight if more than equal to $40 \%$ [3]. According to the results of Nutritional Status Monitoring (Pemantauan Status Gizi or PSG) in 2015 conducted by the Ministry of Health, 29\% of children under five in Indonesia belong to the short body category. More specifically, the lowest prevalence is in Bangka 
Belitung (25.2\%) and the highest in East Nusa Tenggara (NTT) (67.3\%), and Bali Province is one of the provinces that has a moderate stunting problem $(33.3 \%)$ [4].

In Bali, the district that has the highest prevalence of stunting is Klungkung, which is $28.3 \%$ [5] and the Communicty Health Centre of Klungkung I is the highest in prevalence. Based on data 2015, in the Health Centre of Klungkung I there were 100 cases of stunting.

According to the results of a number of previous studies there are several risk factors associated with the incidence of stunting in infants, such as short pregnancy distance, mother height, Low Birth Weight (LBW), number of children, age of breastfeeding complementary feeding (Makanan Pendamping Air Susu Ibu or MP-ASI), exclusive breastfeeding (Air Susu Ibu or ASI), and frequency of infection history. Based on the above factors, this study is conducted to examine the risk factors that lead stunting in children under five in Community Health Centre of Klungkung I in 2016/2017.

\section{Method}

This study is a case-control type with a retrospective approach. Additionally the study was conducted at the Community Health Centre of Klungkung I for 6 months, from August 2017 to January 2018. The subjects of the study were selected by applying a purposive sampling technique to 105 people, comprising 35 persons in the case group and 70 persons in the control group. The inclusion criteria were stunting children under five, domiciled in the location of the study area, and signed an informed consent; while the exclusion criteria used were children under five with a diagnosis of not stunting, not having complete data, and not being at the location during the conduction of the study. Data on risk factors and stunting patients were collected and presented in a categorical form, namely in the form of tables and narratives. Data analysis was carried out bivariately by chi-square test and multivariate with multiple logistic regression methods.

\section{Results And Discussion}

\subsection{Overview of the Study Subjects}

As shown in table 1, children under five who experience more stunting incidence are male $(68.57 \%)$. Conversely, children under five who tend to be more normal are female $(51.43 \%)$. Viewed from age, the stunting cases are more common in children under five aged 48-59 months $(34.29 \%)$, while normal children are mostly 12 to 23 months old (50.00\%). From the results of the study, the characteristics of the subject were obtained as in table 1.

Table 1. Characteristics of the Study Subjects

\begin{tabular}{lcc}
\hline \multicolumn{1}{c}{ Characteristics } & Case & Control \\
\hline Genre & & \\
Male & 24 & 34 \\
Female & 11 & 36 \\
Age & & \\
0-11 months & 2 & 5 \\
12-23 months & 6 & 35 \\
$24-35$ months & 8 & 10 \\
\hline
\end{tabular}




\begin{tabular}{ccc}
\hline Characteristics & Case & Control \\
\hline $36-47$ months & 7 & 11 \\
$48-59$ months & 12 & 9 \\
\hline
\end{tabular}

\subsection{Overview of the Mothers of the Study Subjects}

As shown in table 2, the education level of the case group is lower than that of the control group, wherein, around $65.72 \%$ of the case group had the last education, that is junior high school and lower, while around $67.14 \%$ of the control group had the last education, high school and above. Judging from the profession, around $37.15 \%$ of the case group had jobs, while in the control group only around $35.70 \%$ had jobs. From the results of the study, mother characteristics of the study subjects are obtained as presented in table 2

Table 2. Characteristics of Mothers of the Study Subjects

\begin{tabular}{lll}
\hline \multicolumn{1}{c}{ Characteristics } & \multicolumn{1}{c}{ Case } & Control \\
\hline Last Education & & \\
Elementary School & 8 & 15 \\
Junior High School & 15 & 31 \\
Senior High School & 12 & 16 \\
Bachelor & 0 & \\
Profession & & 45 \\
Housewife & 22 & 12 \\
Civil Service & 3 & 8 \\
entrepreneur & 5 & 5 \\
Others & 5 & \\
\hline
\end{tabular}

Table 3. . Bivariate Analysis of the Risk Factors of Stunting

\begin{tabular}{|c|c|c|c|c|c|c|c|}
\hline \multirow[t]{2}{*}{ Risk Factor } & \multirow[t]{2}{*}{ Category } & \multirow{2}{*}{$\begin{array}{l}\text { Case } \\
\text { Group }\end{array}$} & \multirow{2}{*}{$\begin{array}{c}\text { Gontrol } \\
\text { Group }\end{array}$} & \multirow[t]{2}{*}{ OR } & \multicolumn{2}{|c|}{$95 \% \mathrm{CI}$} & \multirow[t]{2}{*}{ p-value } \\
\hline & & & & & Lower & Upper & \\
\hline \multirow{3}{*}{$\begin{array}{l}\text { Distance of } \\
\text { pregnancy }\end{array}$} & $<2$ Years & 18 & 37 & \multirow{3}{*}{0,94} & \multirow{3}{*}{0,42} & \multirow{3}{*}{2,13} & \multirow{3}{*}{0,890} \\
\hline & $\geq 2$ Years & 17 & 33 & & & & \\
\hline & Total & 35 & 70 & & & & \\
\hline Height of & $<150 \mathrm{~cm}$ & 10 & 5 & \multirow{3}{*}{5,20} & \multirow{3}{*}{1,62} & \multirow{3}{*}{16,73} & \multirow{3}{*}{$0,003 *$} \\
\hline \multirow[t]{2}{*}{ Mother } & $\geq 150 \mathrm{~cm}$ & 25 & 65 & & & & \\
\hline & Total & 35 & 70 & & & & \\
\hline \multirow[t]{3}{*}{ LBW } & $<2500 \mathrm{gr}$ & 5 & 1 & \multirow{3}{*}{11,50} & \multirow{3}{*}{1,28} & \multirow{3}{*}{102,69} & \multirow{3}{*}{$0,026^{*}$} \\
\hline & $\geq 2500 \mathrm{gr}$ & 30 & 69 & & & & \\
\hline & Total & 35 & 70 & & & & \\
\hline Number of & $>2$ children & 19 & 43 & \multirow{3}{*}{0,75} & \multirow[t]{3}{*}{0,33} & \multirow{3}{*}{1,69} & \multirow{3}{*}{0,483} \\
\hline Children & $\leq 2$ children & 16 & 27 & & & & \\
\hline & Total & 35 & 70 & & & & \\
\hline \multirow{3}{*}{$\begin{array}{l}\text { Age of } \\
\text { breastfeeding }\end{array}$} & $<6,>6$ & 24 & 26 & \multirow{3}{*}{3,69} & \multirow{3}{*}{1,56} & \multirow{3}{*}{8,75} & \multirow{3}{*}{$0,002 *$} \\
\hline & months & 11 & 44 & & & & \\
\hline & $\begin{array}{l}\leq 6 \text { months } \\
\text { Total }\end{array}$ & 35 & 70 & & & & \\
\hline \multirow{3}{*}{$\begin{array}{l}\text { Exclusive } \\
\text { breastfeeding }\end{array}$} & $<6$ months & 19 & 19 & \multirow{3}{*}{3,18} & \multirow{3}{*}{1,36} & & \\
\hline & $\geq 6$ months & 16 & 51 & & & 7,45 & $0,006^{*}$ \\
\hline & Total & 35 & 70 & & & & \\
\hline Frequency of & $\geq 2$ times & 23 & 24 & & & & \\
\hline & $<2$ times & 12 & 46 & 3,67 & 1,56 & 8,64 & $0,002 *$ \\
\hline
\end{tabular}




\begin{tabular}{|c|c|c|c|c|c|c|c|}
\hline \multirow[t]{2}{*}{ Risk Factor } & \multirow[t]{2}{*}{ Category } & \multirow{2}{*}{$\begin{array}{c}\text { Case } \\
\text { Group }\end{array}$} & \multirow{2}{*}{$\begin{array}{c}\text { Gontrol } \\
\text { Group }\end{array}$} & \multirow[t]{2}{*}{ OR } & \multicolumn{2}{|c|}{$95 \% \mathrm{CI}$} & \multirow[t]{2}{*}{ p-value } \\
\hline & & & & & Lower & Upper & \\
\hline infectionhistory & Total & 35 & 70 & & & & \\
\hline
\end{tabular}

Table 4. Multivariate Analysis of the Risk Factors of Stunting

\begin{tabular}{|c|c|c|c|c|}
\hline \multirow{2}{*}{ Risk Factor } & \multirow{2}{*}{ OR } & \multicolumn{2}{|c|}{$95 \% \mathrm{CI}$} & \multirow{2}{*}{$p$-value } \\
\hline & & Lower & Upper & \\
\hline Height of Mother & 7,37 & 1,94 & 28,02 & $0,003 *$ \\
\hline LBW & 21,98 & 2,04 & 237,69 & $0,011 *$ \\
\hline $\begin{array}{l}\text { Age of } \\
\text { breastfeeding }\end{array}$ & 3,16 & 0,75 & 13,29 & 0,116 \\
\hline $\begin{array}{l}\text { Exclusive } \\
\text { breastfeeding }\end{array}$ & 1,04 & 0,25 & 4,39 & 0,956 \\
\hline $\begin{array}{l}\text { Frequency of } \\
\text { infection history }\end{array}$ & 2,54 & 0,83 & 7,79 & 0,103 \\
\hline
\end{tabular}

\subsection{Relationship between Pregnancy Distance and Stunting}

Based on the results of the study, the distance of pregnancy is not a risk factor and is not a protective factor against the incidence of stunting. This result is similar to the results of a study conducted by Fajrina [6], but is different from that found by Candra [7].

In addition, the results of data analysis also revealed that the distance of pregnancy is not a risk factor for the incidence of stunting in children under five. This could happen because most of the mothers at the Community Health Centre of Klungkung I serve as housewives so they have enough time to take care for their children.

\subsection{Relationship between Height of Mother and Stunting}

In consonance with the results of the study, the height of mother is a risk factor for the incidence of stunting and statistically significant. These result is similar to those conducted by Nadiyah et al. [3] but is different from those found by Kusuma [8].

Height is one form of genetic expression and is a factor that is inherited to children. Children with short stature parents, either one or both, are more at risk of growing shorter than children with parents of normal height. The gene itself is a hereditary carrier factor, in that, the properties carried by the individual are determined by genes [8].

\subsection{Relationship between Low Birth Weights (LBW) and Stunting}

Another finding of this study is that LBW is a risk factor for the incidence of stunting and statistically significant. Such results confirm the result of research conducted by Putra [9] and Nadiyah et al. [3] but is contrary to the result found by Nasikhah [10] in her study.

LBW has a very strong relationship with the health and survival of newborns. Besides being able to disrupt the growth and development of the baby, this condition can also interfere with cognitive growth and development as well as vulnerability to chronic diseases in the future. Babies born with $\mathrm{LBW}$ tend to be difficult to catch up with early growth. The lag of growth will cause children to become stunting [9].

\subsection{Relationship between Number of Children and Stunting}

Based on the results of the study, the number of children is not a risk factor and is not a protective factor against the incidence of stunting in children under five at the Community 
Health Centre of Klungkung I. This result is contrary to the results of study conducted by Candra [7].

The number of children is not a risk factor for the incidence of stunting because the number of families who have children more than two people is not small, in which respectively one of their children has worked and is able to live independently. This means that the burden on parents to support their children is reduced.

\subsection{Relationship between the Age of Breastfeeding as a Complementary Feeding and Stunting}

Based on the results of the study, the age of Breastfeeding as a Complementary Feeding is not a risk factor for the incidence of stunting through multivariate analysis. This is similar to the results of a study conducted by Lestari et al. [11] but is different from the results found by Anugraheni [12] in his study.

Proper breastfeeding as a complementary feeding will enhance the immune system and provide protection from disease. The breastfeeding as a complementary feeding that is too early will reduce consumption in breast milk. This will facilitate the entry of various types of germs. The delay in breastfeeding as a complementary feeding, however, also affects the growth of the baby. The consequences that can arise due to delay in breastfeeding as a complementary feeding are failure to thrive, iron deficiency, and growth and development disorders [11].

\subsection{Relationship between Exclusive Breastfeeding and Stunting}

As indicated by the results of data analysis of the present study, exclusive breastfeeding is not a risk factor for stunting incidence through multivariate analysis. These findings are similar to those revealed by Lestari et al. [11] but are different from the results of research conducted by Anugraheni [12].

The effect of exclusive breastfeeding on changes in stunting status is caused by the function of breast milk as immunity and antibodies to prevent infection. Babies who do not get exclusive breastfeeding will be more susceptible to infection which later can affect their growth and development [13].

\subsection{Relationship between Frequency of Infection History and Stunting}

The results of data analysis of this study revealed that the frequency of infection history is not a risk factor for the incidence of stunting through multivariate analysis. The results of the present study confirm the results of the research conducted by Welasasih and Wirjatmadi [14] and Novitasari [15] but oppose the results of the research conducted by Nasikhah [10].

The impact of infection on growth, such as decreased body weight due to loss of appetite, so that energy and nutrient intake is very lacking for body needs. If this condition occurs for a long time and is not immediately addressed, a disruption in growth will occur [14].

\section{Conclusions}

The height of mother and LBW are risk factors for the incidence of stunting in children under five at the Community Health Centre of Klungkung I. The distance of pregnancy, number of children, the age of breastfeeding as a complementary feeding, exclusive 
breastfeeding, and the frequency of infection history are not the risk factors for the incidence of stunting in children under five at the Community Health Centre of Klungkung I.

\section{References}

[1] Global Nutririon Report. 2014. Nutrition Country Profile Indonesia. International Food Policy Research Institute.

[2] WHO. 2010. Nutrition Landscape Information System (NLIS) Country Profile Indicators. Geneva.

[3] Nadiyah N, Briawan D, Martianto D. 2014. Faktor Risiko Stunting pada Anak Usia 0-23 Bulan Di Provinsi Bali, Jawa Barat, Dan Nusa Tenggara Timur, Jurnal Gizi dan Pangan, Juli 2014, 9(2): 125-132.

[4] Muljati S, Triwinarto A, Budiman B. 2011. Determinan Stunting pada Anak Usia 2-3 Tahun di Tingkat Provinsi (Determinants Of Stunting In Children 2-3 Years Of Age At Privince Level), PGM 2011, 34(1): 50-62.

[5] Balitbangkes. 2008. Laporan RISKESDAS 2007 Provinsi Bali.

[6] Fajrina N. 2016. Hubungan Faktor Ibu dengan Kejadian Stunting pada Balita di Puskesmas Piyungan Kabupaten Bantul [naskah publikasi]. Yogyakarta (Indonesia): Universitas Aisyiyah Yogyakarta.

[7] Candra A. 2013. Hubungan Underlying Factors dengan Kejadian Stunting pada Anak 1 sampai 2 Th [Skripsi]. Semarang (Indonesia): Universitas Diponegoro Semarang.

[8] Kusuma K. 2013. Faktor Risiko Kejadian Stunting pada Anak Usia 2-3 Tahun [skripsi]. Semarang (Indonesia): Universitas Diponegoro.

[9] Putra O. 2016. Pengaruh BBLR Terhadap Kejadian Stunting pada Anak Usia 12-60 Bulan di Wilayah Kerja Puskesmas Pauh Tahun 2015 [Skripsi]. Padang: Fakultas Kesehatan Masyarakat Universitas Andalas.

[10] Nasikhah R. 2012. Faktor Risiko Kejadian Stunting pada Balita Usia 24-36 Bulan di Kecamatan Semarang Timur [skripsi]. Semarang (Indonesia): Universitas Diponegoro.

[11] Lestari MU, Lubis G, Pertiwi D. 2014. Hubungan Pemberian Makanan Pendamping ASI (MPASI) dengan Status Gizi Anak Usia 1-3 Tahun di Kota Padang Tahun 2012, Jurnal Kesehatan Andalas, vol. 3, no. 2, pp. 188-190.

[12] Anugraheni HS. 2012. Faktor Risiko Kejadian Stunting pada Anak Usia 12-36 Bulan di Kecamatan Pati, Kabupaten Pati [skripsi]. Semarang (Indonesia): Universitas Diponegoro.

[13] Rohmatun NY. 2014. Hubungan Tingkat Pendidikan Ibu dan Pemberian ASI Eksklusif dengan Kejadian Stunting pada Balita di Desa Sidowarno Kecamatan Wonosari Kabupaten Klaten, Naskah Publikasi Universitas Muhamadiyah Surakarta.

[14] Welasasih BD, Wirjatmadi B. 2012. Beberapa Faktor yang Berhubungan dengan Status Gizi Balita Stunting. Surabaya: Departemen Gizi Kesehatan Universitas Airlangga.

[15] Novitasari D. 2012. Faktor-Faktor Risiko Kejadian Gizi Buruk pada Balita yang Dirawat di RSUP Dr. Kariadi Semarang [karya tulis ilmiah]. Semarang (Indonesia): Universitas Diponegoro. 